TITLE:

\title{
MARINE HYDROIDS FROM GREECE
}

AUTHOR(S):

Yamada, Mayumi

CITATION:

Yamada, Mayumi. MARINE HYDROIDS FROM GREECE. PUBLICATIONS OF THE SETO MARINE BIOLOGICAL LABORATORY 1965, 12(5): 359-362

ISSUE DATE:

1965-03-10

URL:

http://hdl.handle.net/2433/175380

RIGHT: 


\title{
MARINE HYDROIDS FROM GREECE ${ }^{1)}$
}

\author{
Mayumi YAMADA \\ Zoological Institute, Faculty of Science, \\ Hokkaido University, Sapporo, Japan
}

The hydroid fauna of Greece has been remained unknown. At the end of November of 1958, I had an opportunity to stay in Greece for several days and collect hydroids at the shore of Piraeus near Athens, and also to examine the hydroid specimens which were preserved in the Zoological Institute of the University of Athens.

The collections were made at some shores of $0-1 \mathrm{~m}$ depth near the Piraeus harbour, and the species of the collected materials are only 6 in number as follows, of which 2 are athecate and 4 thecate ones:

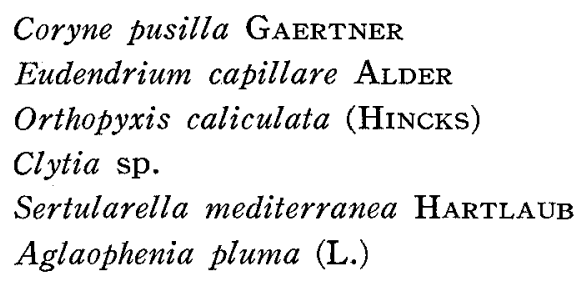

All the identified species have hitherto been known from the Mediterranean Sea.

The materials preserved in the University of Athens were collected in these several years from some different localities near Athens. The materials, all mounted on slides, were unfortunately unlabelled, so the exact localities and dates were not determined. Six species were found among them as follows:

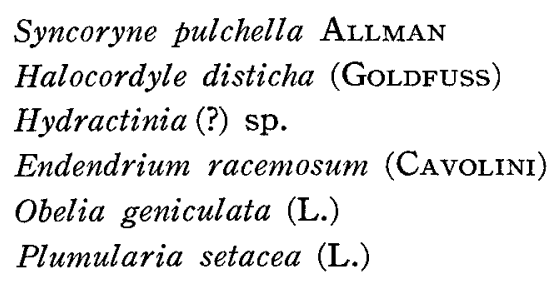

Although the following notes is very brief, it seems to me that the knowledge of the Greek hydroids will be useful for consideration of the distribution of the Mediterranean hydroid fauna.

1) Contribution No. 673 from the Zoological Institute, Faculty of Science, Hokkaido University.

Publ. Seto Mar. Biol. Lab., XII (5), 1965. (Article 27) 
I beg to express here my thanks to Prof. G. PANDAzis and Dr. J. Ondrias, of the University of Athens, for their kindness showed me during my stay in Greece, as also to Prof. T. UchidA for his kind guidance in the preparation of the paper.

\section{Coryne pusilla GAERTNER}

Coryne pusilla: Heller, 1868, p. 31; WeismanN, 1883, p. 49 ; Lo Bianco, 1909, p. 541 ; STEChOW, 1919, p. 5, fig. A ; RIEDL, 1959, p. 603.

Several colonies with male and female gonophores were collected by me at the shore near Piraeus. The species is widely distributed in the world. In the Mediterranean: Nice, Naples, Venice.

\section{Syncoryne pulchella ALLMAN}

Syncoryne pulchella: Lo BiANco, 1909, p. 545 ; Rossi, 1950.

Sarsia tubulosa : RIEDL, 1959, p. 602.

Some fragments of colonies of this species with medusa buds of different development were found among the preserved materials in the University of Athens. The number of tentacles is rather small, about 10-15. The hydroid has been known from the Atlantic and the Mediterranean. In the Mediterranean: Rapallo, Naples.

\section{Halocordyle disticha (GoLDFUSs)}

Pennaria cavolini: Lo BiAnco, 1909 , p. 544.

Pennaria disticha: NePPI, 1919, p. 48 ; NePPI, 1920, p. 22 ; BILlard, 1933, p. 5.

Halocordyle disticha: VERVOORT, 1946, p. 289 ; RIEDL, 1959, p. 606.

Some fragments of a colony of this species were found among the preserved specimens. Some hydranths bear medusa buds of different size. An advanced stage of the buds shows 4 radial canals and 4 tentacular bulbs. The stem is rather smooth with some indistinct annulations. The species is widely distributed in the Atlantic and the Mediterranean. In the Mediterranean: Rapallo, Naples.

\section{Hydractinia (?) sp.}

A small piece of a colony of Hydractinia (?) was found among the preserved specimens. The material is of a detached piece from an unknown substratum. It contains normal gastrozooid polyps and short chitinous spines, and the hydrorhiza is covered with coenosarc. It is now unable to me to identitify this species. 


\section{Eudendrium capillare ALDER}

Eudendrium capillare: WeISManN, 1883, p. 91 ; Lo Bianco, 1909, p. 542; STEchow, 1919, p. 31; Stechow, 1923, p. 80.

Eudendrium capillale var. mediterranea: NEPPI, 1919, p. 3 ; NEPPI, 1920, p. 20.

Several small colonies were collected by me from the Piraeus harbour. The colonies have male gonophores which are 2 or 3 -chambered and borne on reduced hydranths. This is widely distributed in the world. In the Mediterranean: Marseilles, Nice, Monaco, Naples.

\section{Eudendrium racemosum (CAVOLINI)}

Eudendrium racemosum: WEISMANN, 1883, p. 92 ; MoTz-KosSOWSKA, 1905, p. 53, 56 ; LoBIANCO, 1909, p. 542 ; NePPI, 1917, p. 33 ; STECHOW, 1919, p. 32 ; NePPI, 1921, p. 21 ; STECHOW, 1923, p. 83 ; MERGNER, 1957, p. 63 ; RIEDL, 1959, p. 621.

Several colonies of this species were found among the preserved materials. The colonies are rather large and contain male and female gonophores. This female gonophores are borne on reduced hydranths, in a whorl of 3-5 in number. This species is one of the common hydroids in the Mediterranean and known from: Banyuls-sur-Mer, Nice, Naples, Trieste, Split. The species is also known from Japan.

\section{Orthopyxis caliculata (Hincks)}

Orthopyxis caliculata: Lo BIANCO, 1909, p. 540 ; NePPI, 1921, p. 1; RIEDL, 1959, p. 633.

Some small colonies attached on a green alga were found by me in the Piraeus harbour. The colonies are very delicate, and contain some gonothecae. The species is rather widely distributed in the world. In the Mediterranean: Ajaccio (Corsica), Naples, Rovigno.

\section{Clytia (?) sp.}

A very small fragment of a colony which is consisted of only 2 polyps is found by me on an alga from the Piraeus harbour. It is impossible to identify such an incomplete material, but it seems to me it would be a Clytia.

\section{Obelia geniculuta (L.)}

Obelia geniculata: Lo BIANCO, 1909 ; p. 543 ; NEPPI, 1917, p. 29 ; STECHOw, 1923, p. 114 ; RIEDL, 1959, p. 636.

Several colonies of this species were found among the preserved specimens. 
This seems to be a common hydroid in the Mediterranean and widely distributed in the world. In the Mediterranean: Villefranche-sur-Mer, Naples.

\section{Sertularella mediterranea Hartlaub}

Sertularella mediterranea: NEPPI, 1917, p. 48; NEPPI, 1921, p. 22; STECHOW, 1923, p. 189; BROCH, 1933, p. 76 ; RIEDL, 1959, p. 649.

Several colonies of the species were collected by me in the shore of Piraeus. The colony attains about $2 \mathrm{~cm}$. PICARD (1958) has an opinion that the materials hitherto treated under this species should be named as Sertularella ellisii var. mediterranea. It is distributed in the Mediterranean and the French Indo-China. In the Mediterranean: Naples, Split.

\section{Plumularia setacea (L.)}

Plumularia setacea: SchneIder, 1897, p. 486 ; Stechow, 1919, p. 119 ; Stechow, 1923, p. 226 ; RIEDL, 1959, p. 656.

Some small pieces of this species were found among the preserved materials. Some gonothecae attached on a piece are elongated attaining $1 \mathrm{~mm}$ in length. It is widely distributed in the world. In the Mediterranean: Villefranche-sur-Mer, Monaco, Naples, Rovigno.

\section{Aglaophenia pluma (L.)}

Aglaophenia pluma: Stechow, 1919, p. 147; SteChow, 1923, p. 248; VeRVOORT, 1946, p. 335, fig. 8 ; RIEDL, 1959, p. 487.

Some small colonies were collected by me from the Piraeus harbour. It is distributed in the Atlantic and the Mediterranean. In the Mediterranean: Marseilles, Naples, Rovigno, Split.

\section{LITERATURE CITED}

BROCH, H. 1912. Hydroidenuntersuchungen III. Vergleichende Studien an adriatischen Hydroiden. Norske Vit. Selsk. Skrift. 1.

Lo BtANCO, S. 1909. Notizie biologiche riguardanti specialmente il periodo di maturità sessuale degli animali del Golfo di Napoli. Mitt. Zool. Stat. Neapel 8.

NePPI, V. 1917. Osservazioni sui polipi del golfo di Napoli. Publ. Staz. Zool. Napoli 2.

—_ 1921. Nuove osservazioni sui polipi idroidi del golfo di Napoli. Ibid. 3.

RiedL, R. 1959. Die Hydroiden des Golfes von Neapel und ihr Anteil an der Fauna unterseeischer Höhlen. Ibid. 30 (Suppl.).

Stechow, E. 1919. Zur Kenntnis der Hydroidenfauna das Mittelmeeres, Amerikas und anderer gebiebe. I. Zool. Jb. Syst. 42.

1923. Zur Kenntnis der Hydroidenfauna des Mittelmeeres, Amerikas und anderer gebiebe. II. Ibid. 47.

WEISmanN, A. 1883. Die Entstehung der Sexualzellen bei Hydromedusen. Jena. 